\title{
Penerapan Model Pembelajaran Problem Based Intruction dengan Media Power Point Guna Meningkatkan Prestasi Belajar IPA
}

\author{
I Made Widya Astawa* \\ SMP Negeri 3 Dawan. Klungkung, Indonesia
}

A R T I C L E I N F O

\section{Article history:}

Received 19 August 2020

Received in revised form

30 September 2020

Accepted 10 October 2020

Available online 29

November 2020

\section{Kata Kunci:}

Model Pembelajaran

Problem Based Intruction,

Media Power Point,

Prestasi Belajar

Keywords:

Problem Based Intruction

Learning Model, Power

Point Media, Learning

Achievement

\begin{abstract}
A B S T R A K
Tujuan penulisan penelitian tindakan kelas ini adalah untuk meningkatkan prestasi belajar IPA melalui penerapan model pembelajaran Problem Based Intruction dengan media power point dalam proses pembelajaran. Metode pengumpulan datanya adalah menggunakan tes prestasi belajar. Metode analisis datanya adalah deskriptif. Hasil yang diperoleh dari penelitian ini adalah model pembelajaran Problem Based Intruction dengan media power point dapat meningkatkan prestasi belajar siswa. Ini terbukti dari hasil yang diperoleh pada awalnya 67,03 pada siklus I menjadi 74,44 dan pada siklus II menjadi 81,11 . Ketuntasan belajar siswa juga mengalami peningkatan yag sangat signifikan. pada awal pertemuaan ketuntasan belajar siswa hanya mencapai $25,92 \%$, pada siklus I meningkat menjadi $66,66 \%$, dan pada siklus II peningkatannya sangat signifikan yaitu mencapai $96,29 \%$. Kesimpulan yang diperoleh dari penelitian ini adalah penggunaan model pembelajaran Problem Based Intruction dengan media power point dapat meningkatkan prestasi belajar IPA.
\end{abstract}

This research was conducted at SMP Negeri 3 Dawan in class VII B, where the ability of students for science subjects is still very low. The purpose of this classroom action research is to improve the science learning achievement of class VII B students of SMP Negeri 3 Dawan in the second semester of the 2018/2019 academic year through the application of the Problem Based Intruction learning model with power point media in the learning process. The data learning method is to use a learning achievement test. The data analysis method is descriptive. The results obtained from this study are the Problem Based Intruction learning model with power point media which can improve student achievement. This is evident from the results obtained initially 67.03 in cycle I to 74.44 and in cycle II to 81.11. Students' learning completeness has also increased significantly. At the beginning of the meeting, students' learning completeness only reached $25.92 \%$, in the first cycle it increased to $66.66 \%$, and in the second cycle the increase was very significant, reaching $96.29 \%$. The conclusion obtained from this research is that the use of the Problem Based Intruction learning model with power point media can improve the science learning achievement of class VII B students of SMP Negeri 3 Dawan in the second semester of the 2018/2019 academic year.

\section{Pendahuluan}

Pendidikan adalah usaha sadar dan terencana untuk mewujudkan suasana belajar dan proses belajar agar peserta didik secara aktif membangun potensi dirinya untuk memiliki kekuatan spiritual keagamaan, pengendalian diri, kepribadian, kecerdasan, akhlak mulia, serta keterampilan yang diperlukan dirinya, masyarakat, bangsa dan negara. Menurut (Yulidatullah, 2018) Pendidikan adalah usaha sadar yang dilakukan sebagai salah satu upaya meningkatkan segala bentuk sumber daya manusia. Pelaksanaan pendidikan dapat berlangsung dalam keluarga, masyarakat dan sekolah. Sehubungan dengan hal tersebut, pelaksanaan pendidikan di sekolah diharapkan akan melahirkan generasi-generasi yang tumbuh dengan 
bekal ilmu pengetahuan dan keterampilan sebagai corak perkembangan bangsa dan negara di masa yang akan datang. Menurut (Munirah, 2015) sistem pendidikan di Indonesia dewasa ini tampak ada kesenjangan antara kenginan dan realita. Secara makro dapat dilihat dalam aspek pengelolaan, peran pemerintah dan masyarakat, kurikulum atau materi ajar, pendekatan dan metodologi pembelajaran, sumber daya manusia, lingkungan kampus atau sekolah, dana, dan akreditasi. Kesenjangan dalam sistem pendidikan tersebut disebabkan karena faktor politik, ekonomi, sosial-budaya dan sebagainya yang selalu berubah sesuai dengan perubahan dan perkembangan zaman. Pendidikan sangat penting dalam pembangunan, maka tidak salah jika pemerintah senantiasa mengusahakan untuk meningkatkan mutu pendidikan baik dari tingkat yang paling rendah maupun sampai ke tingkat perguruan tinggi. Berbagai upaya telah dilakukan oleh pemerintah untuk meningkatkan mutu pendidikan, salah satunya yaitu penyempurnaan terhadap kurikulum. Kurikulum merupakan seperangkat rencana dan pengaturan mengenai tujuan, isi, dan bahan pelajaran serta cara yang digunakan sebagai pedoman penyelenggaraan kegiatan pembelajaran untuk mencapai tujuan pendidikan tertentu.

Dalam proses mencerdaskan bangsa, guru merupakan ujung tombak dalam peningkatan kualitas pendidikan sehingga semakin tinggi kualitas guru maka kualitas pendidikan diharapkan juga meningkat, dengan demikian idealnya mampu menjawab semua permasalahan yang dimiliki bangsa baik yang berupa material maupun sepiritual. Agar pendidikan dapat berhasil sesuai dengan tujuan diperlukan berbagai sarana atau sumberdaya seperti bangunan sekolah, buku/materi pelajaran, guru dan sarana pendukung lainnya. Berkaitan dengan profesionalisme guru, khususnya guru pembimbing perlu dicermati lagi, apakah sudah optimal menjalankan tugasnya atau belum dalam mendampingi peserta didik mengatasi permasalahan yang dialami yang menyangkut dimensi kemanusiaan mereka. Khususnya peserta didik di Sekolah Menengah Atas yang harus mempersiapkan diri untuk bekerja di masyarakat membutukan life skills yang cukup, agar peserta didik tidak canggung melangkah dan berani menghadapi masalah. Untuk itu menuntut semangat kerja guru pembimbing dalam membantu peserta didik mengubah perilaku yang kurang baik menuju perilaku yang diharapkan di dunia pendidikan.salah asatu mata pelajaran yang bisa mengabangakan kemampaun siswa tersebut dalah IPA.

Mata pelajaran Ilmu Pengetahuan Alam (IPA) merupakan mata pelajaran pokok pada jenjang pendidikan Sekolah Menengah Pertama (SMP). Dalam pembelajaran IPA terdapat kosep-konsep IPA yang memiliki keterkaitan dengan kehidupan sehari-hari, juga memiliki keterkaitan dengan pemecahan masalah yang ditemukan dalam kehidupan sehari-hari, sehingga diperlukan suatu model pembelajaran IPA yang sesuai agar mudah dipelajari. Tujuan pembelajaran IPA diarahkan untuk mencapai kompetensi Inti dan Kompetensi Dasar pada mata pelajaran IPA. Mata pelajaran IPA di sekolah diharapkan dapat menjadi wahana bagi siswa untuk mempelajari diri sendiri dan alam sekitar, serta upaya-upaya pengembangan untuk diterapkan dalam kehidupan sehari-hari. Melalui pembelajaran IPA terpadu diharapkan peserta didik dapat memperoleh pengalaman langsung, sehingga dapat menambah kekuatan untuk menerima, menyimpan, dan menerapkan konsep yang telah dipelajarinya. Dengan demikian, peserta didik terlatih untuk dapat menemukan sendiri berbagai konsep yang dipelajari secara menyeluruh (holistik), bermakna, autentik dan aktif. Berdasarkan kurikulum 2013 untuk SMP/MTs, mata pelajaran fisika, kimia, dan biologi harus diorganisasikan dalam satu pelajaran IPA (Ilmu Pengetahuan Alam). Pengorganisasian ini dilakukan karena mata pelajaran fisika, kimia, dan biologi merupakan rumpun Ilmu Pengetahuan Alam. Konsep yang terdapat dalam matapelajaran fisika, biologi, dan kimia merupakan konsep-konsep yang menyusun IPA sehingga dalam pembelajarannya tidak disampaikan secara terpisah. Dengan pembelajaran IPA Terpadu siswa akan memahami materi IPA secara holistik. Hal ini sesuai dengan peraturan menteri pendidikan dan kebudayaan nomor 81a tahun 2013 tentang implementasi kurikulum 2013 yang menyatakan secara tegas bahwa isi mata pelajaran Ilmu Pengetahuan Alam (IPA) pada SMP/MTs merupakan IPA Terpadu. Konsep pembelajarannya dikembangkan sebagai mata pelajaran integrative science atau "IPA Terpadu" bukan sebagai pendidikan disiplin ilmu. Konsep keterpaduan ini ditunjukkan dalam Kompetensi Inti (KI) dan Kompetensi Dasar (KD) pembelajaran IPA yakni di dalam satu KD sudah memadukan konsep-konsep IPA dari bidang ilmu biologi, fisika, dan ilmu pengetahuan bumi dan antariksa (IPBA) (Kemendikbud, 2013). Pedoman Pengembangan Kurikulum 2013 menyebutkan bahwa pembelajaran IPA berorientasi pada kemampuan aplikatif, pengembangan kemampuan berpikir, kemampuan belajar, rasa ingin tahu, dan pengembangan sikap peduli dan bertanggung jawab terhadap lingkungan sosial dan alam. Namun tujuan dari pembelajaran IPA tersebut belum terhujud, hal ini nampak dari hasil wawancara yang dilkukan.

Bedasarkan observasi dan wawancara yang dilakukan di SMP Negeri 3 Dawan, selama ini pembelajaran IPA masih banyak dilakukan secara konvensional/tradisional (pembelajaran berpusat pada guru) serta lemahnya kemampuan guru dalam mendorong dan memotivasi siswa menjadikan prestasi belajar IPA masih rendah bila dibandingkan dengan mata pelajaran lainnya. Hal tersebut peneliti temukan pada saat melakukan observasi di kelas VII B pada semester II tahun pelajaran 2018/2019. dimana 
pelajaran IPA selalu disajikan secara verbal melalui kegiatan ceramah dan textbook oriented, dengan keterlibatan siswa yang sangat minim karena siswa hanya melakukan kegiatan duduk, diam, mendengar, mencatat dan menghafal, sehingga kurang menarik minat siswa dan membosankan yang akhirnya membuat siswa mudah lupa terhadap konsep yang telah diberikan, sehingga nilai rata-rata mata pelajaran ini hanya mencapai rata-rata 67,03 dan prosentase ketuntasan mata pelajaran IPA siswa kelas VII B semester II tahun pelajaran 2018/2019 hanya mencapai $25,92 \%$. Karena rendahnya prestasi belajar IPA siswa seperti yang telah disampaikan di atas, memotivasi peneliti untuk melakukan perbaikan pembelajaran. Perbaikan tersebut peneliti lakukan dengan menerapkan langkah-langkah model pembelajaran Problem Based Intruction dengan media power point dalam proses belajar mengajar.

Meurut (Listiowati, 2013) Pembelajaran berbasis masalah atau Problem Based Instruction dikembangkan untuk membantu siswa mengembangkan kemampuan berpikir, pemecahan masalah, keterampilan intelektual, dan belajar berbagai peran dengan dewasa melalui pelibatan mereka dalam pengalaman nyata atau simulasi, serta menjadi siswa yang otonom dan mandiri. Model pembelajaran Problem Based Intruction menggunakan pendekatan pembelajaran siswa pada masalah kehidupan nyata. Problem Based Intruction dikembangkan untuk membantu siswa mengembangkan kemampuan berpikir, pemecahan masalah dan keterampilan intelektual, belajar berbagai peran, melalui pengalaman belajar dalam kehidupan nyata. Arends (Trianto, 2007) menjelaskan bahwa Problem Based Intruction merupakan pendekatan belajar yang menggunakan permasalahan autentik dengan maksud untuk menyusun pengetahuan siswa, mengembangkan inkuiri dan keterampilan berpikir tingkat lebih tinggi, mengembangkan kemandirian dan percaya diri.

Problem Based Intruction berpusat pada siswa. Problem Based Intruction merupakan salah satu dari berbagai model pembelajaran yang dapat digunakan guru dalam mengaktifkan siswa dalam belajar (Abbas et al., 2007). Guru berkewajiban menggiring siswa untuk melakukan kegiatan. Guru sebagai penyaji masalah, memberikan instruksi-instruksi, membimbing diskusi, memberikan dorongan dan dukungan yang dapat meningkatkan pertumbuhan inkuiri. Guru diharapkan dapat menberikan kemudahan belajar melalui penciptaan iklim yang kondusif dengan menggunakan fasilitas media dan materi pembelajaran yang bervariasi. Pelaksanaan Problem Based Intruction didukung dengan beberapa metode mengajar diantaranya metode ceramah, Tanya jawab, diskusi, penemuan dan pemecahan masalah. Problem Based Intruction mengacu pada inkuiri, kontruktivisme dan menekankan pada berpikir tingkat tinggi. Model ini efektif untuk mengajarkan proses - proses berpikir tingkat tinggi, membantu siswa membangun sendiri pengetahuannya dan membantu siswa memproses informasi yang telah dimiliki. Problem Based Intruction menggunakan masalah dunia nyata sebagai konteks untuk belajar tentang cara berpikir kritis dan keterampilan pemecahan masalah. Lingkungan belajar yang terbuka menuntut peran aktif siswa untuk melakukan penyelidikan terhadap masalah sehingga menjadi pembelajar yang mandiri. Penelitian yang dilakukan oleh (Suhita, 2019) menyatakan bahwa model pembelajaran Problem Based Instruction dapat meningkatkan kemampuan berpikir kritis peserta didik, dimana kemampuan berpikir kritis peserta didik meningkat dari setiap siklusnya. Kemudian penelitian yang dilakukan oleh (Anggis, 2017) menyatakan bahwa motivasi belajar siswa meningkat dari siklus sebelumnya dan lebih baik dari pembelajaran sebelum diberikan tindakan kelas dengan model pembelajaran Problem Based Instruction.

Model pembelajaran Problem Based Intruction akan lebih efektif lagi diterapkan apabila dipadukan dengan media power point. Media power point merupakan suatu software yang akan membantu dalam menyusun sebuah persentase yang efektif, profesional, dan juga mudah. Power point akan membantu sebuah gagasan menjadi lebih menarik dan jelas tujuannya jika dipersentasikan karena power point akan membantu dalam pembuatan slide, outline persentase, persentase elektronika, menampilkan slide yang dinamis, clip art yang menarik, yang semua itu mudah ditampilkan di layar monitor komputer. Penelitian yang dilakukan oleh (Minardi \& Akbar, 2020) menyatakan bahwa terciptanya Belajar mengajar yang lebih baik dengan memanfaatkan teknologi informasi khususnya Microsoft PowerPoint untuk membuat media belajar yang interaktif. Kemudian penelitian yang dilakukan oleh (Susanti et al., 2020) menyatakan bahwa media powerpoint pada pembelajaran bahasa Arab dalam kategori tinggi, yang dibuktikan dengan median 82,5 .

Hasil penelitian ini sejalan dengan hasil penelitian yang dilakukan oleh Purwanto pada tahun 2016 dengan judul Penggunaan Model Problem Based Learning Dengan Media Powerpoint Untuk Meningkatkan Minat Belajar Siswa. Dalam penelitiannya disimpulkan bahwa model Problem Based Learning Dengan Media Powerpoint membuat pembelajaran di kelas menjadi lebih bermakna sehingga secara efektif dapat meningkatkan minat belajar siswa. Selanjutnya penelitian yang dilakukan oleh Hariata, dkk pada tahun 2017 dengan judul Pengaruh Model Pembelajaran Problem Based Instruction berbantuan Media Powerpoint Terhadap Hasil Belajar IPS. Hasil penelitian menunjukan bahwa terdapat perbedaan hasil belajar IPS antara kelompok siswa yang dibelajarkan dengan menggunakan model pembelajaran Problem 
Based Instruction berbantuan media powerpoint dan kelompok siswa yang dibelajarkan dengan menggunakan pembelajaran konvensional pada siswa kelas V SD di Gugus X Kecamatan Buleleng.

Berdasarkan jabaran tersebut maka dirumuskan Tujuan penulisan penelitian tindakan kelas ini adalah untuk meningkatkan prestasi belajar IPA melalui penerapan model pembelajaran Problem Based Intruction dengan media power point dalam proses pembelajaran.

\section{Metode}

Penelitian ini dilakukan di SMP Negeri 3 Dawan. Lingkungan sekolah ini sangat nyaman karena hubungan dengan masyarakat sekitar sekolah sangat baik, hubungan antara sekolah dengan masyarakat sekitar juga sangat harmonis, sehingga menimbulkan rasa mutualisme antara sekolah dan masyarakat sekitar.

Penelitian yang dilakukan termasuk penelitian tindakan. Oleh karenanya, rancangan yang khusus untuk sebuah penelitian tindakan sangat diperlukan. Berdasarkan sudut pandang pencapaian tujuan penelitian, rancanganpenelitian berfungsi sebagai pedoman kerja (peta pedoman pengarahan bagipelaksanaan penelitian). Oleh karenanya, rancangan penelitian harus jelas, singkat dan memberikan petunjuk operasional tentang apa yang sebaiknyadilakukan dan bagaimana cara serta teknik melakukannya. Fungsi lain, rancangan penelitian adalah sebagai rambu-rambu penentuan atau tolok ukurkeberhasilan penelitian yang akan dilaksanakan. Memberikan petunjuk mengenaiukuran-ukuran sampai dimana penelitian yang dilakukan itu dikatakan mencapai hasil yang diinginkan.

Untuk penelitian ini penulis memilih rancangan penelitian tindakan yang disampaikan Mc. Kernan seperti terlihat pada gambar berikut.

\section{Mc. Kernan}

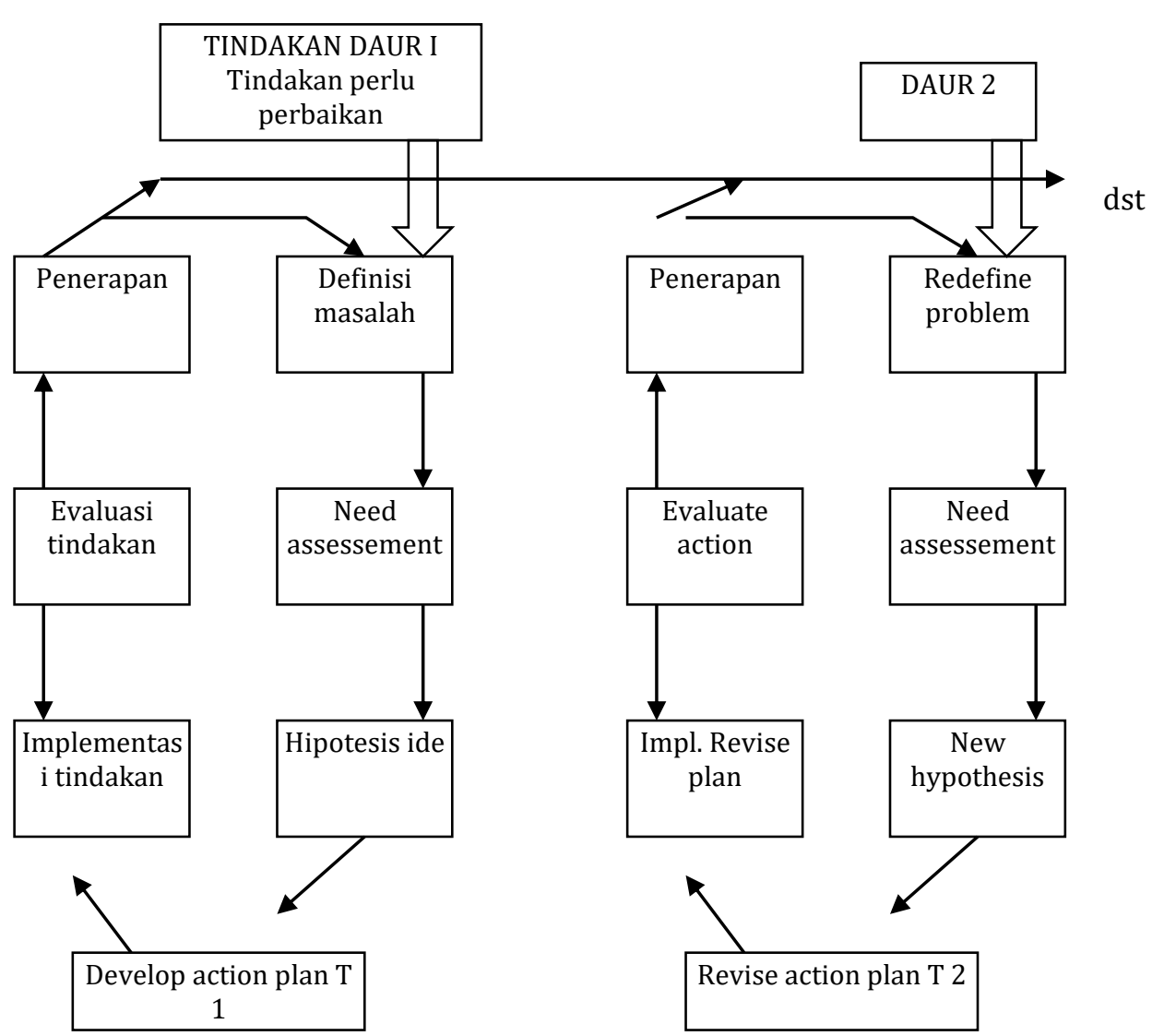

Gambar 1. Penelitian Tindakan Model Mc. Kernan, 1991

(dalam (Sukidin et al., 2002) 


\section{Prosedur:}

Tindakan daur I: mulai dari definisi masalah, berlanjut ke assessment yang disiapkan, berlanjut ke rumusan hipotesis, berlanjut ke pengembangan untuk tindakan I, lalu implementasi tindakan, evaluasi tindakan berlanjut ke penerapan selanjutnya.

Tindakan daur II: mulai dari menentukan kembali masalah yang ada, berlanjut ke assessment yang disiapkan, terus ke pemikiran terhadap munculnya hipotesis yang baru, perbaikan tindakan pada rencana ke 2, pelaksanaan tindakan, evaluasi terhadap semua pelaksanaan dan penerapan

\section{Hasil dan Pembahasan}

Pada penelitian ini, data awal yang diperoleh dengan rata-rata 67,03 dengan ketuntasan belajar hanya mencapai $25,92 \%$ menunjukkan bahwa kemampuan siswa dalam mata pelajaran IPA masih sangat rendah mengingat kriteria ketuntasan belajar siswa untuk mata pelajaran ini di SMP Negeri 3 Dawan adalah 73,00 . Dengan nilai yang sangat rendah seperti itu maka peneliti mengupayakan untuk dapat meningkatkan prestasi belajar anak/siswa menggunakan metode/model pembelajaran Problem Based Intruction dengan media power point. Akhirnya dengan penerapan metode/model pembelajaran Problem Based Intruction dengan media power point yang benar sesuai teori yang ada, peningkatan rata-rata prestasi belajar anak/siswa pada siklus I dapat diupayakan dan mencapai rata-rata 74,44. Namun ratarata tersebut belum maksimal karena hanya 18 siswa memperoleh nilai di atas KKM sedangkan yang lainnya belum mencapai KKM. Sedangkan prosentase ketuntasan belajar mereka baru mencapai 66,66\%. Hal tersebut terjadi akibat penggunaan metode/model pembelajaran Problem Based Intruction dengan media power point belum maksimal dapat dilakukan disebabkan penerapan model/metode tersebut baru dicobakan sehingga guru masih belum mampu melaksanakannya sesua alur teori yang benar. Pelaksanaan pembelajaran pada siklus II terlihat lebih baik dari siklus I, hal ini tentunya berdampak positif terhadap peningkatan prestasi belajar siswa. Rata-rata prestasi belajar siswa pada siklus II meningkat menjadi 81,11 dengan presentase ketuntasan mencapai $96,29 \%$. Hal ini menunjukkan terjadinya peningkatan yang sangat signifikan. Hasil ini mengindikasikan bahwa model/metode pembelajaran Problem Based Intruction dengan media power point mampu meningkatkan prestasi belajar IPA siswa kelas VII B SMP Negeri 3 Dawan pada semester II tahun pelajaran 2018/2019.

Hasil penelitian ini dapat dirangkum pada Tabel 1 dan gambar 1 berikut.

Tabel 1. Tabel Data Prestasi Belajar Siswa Kelas VII B SMP Negeri 3 Dawan

\begin{tabular}{lccc}
\hline \multicolumn{1}{c}{ DATA } & AWAL & SIKLUS I & SIKLUS II \\
\hline Rata Rata Kelas & 67,03 & 74,44 & 81,11 \\
Persentase Ketuntasan & $25,92 \%$ & $66,66 \%$ & $96,29 \%$ \\
\hline
\end{tabular}

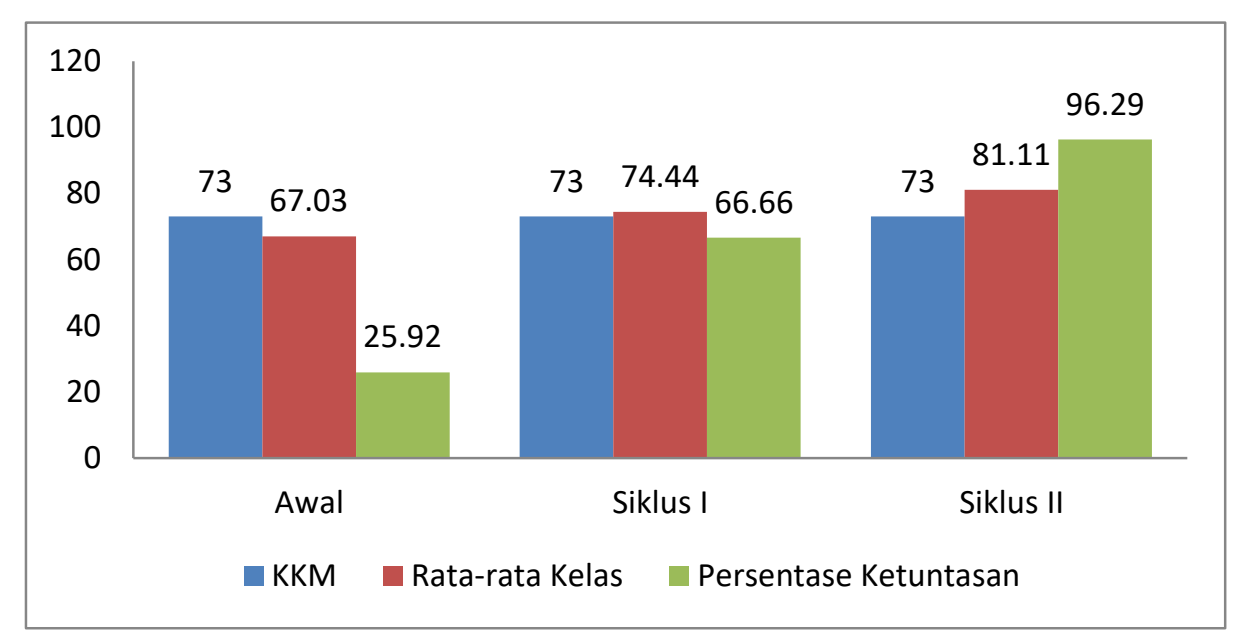

Gambar 2. Grafik Histogram Prestasi Belajar IPA Siswa Kelas VII B SMP Negeri 3 Dawan

Berdasarkan hasil penelitian yang yang sudah dijabarkan pada tabel i dan gambar 1 diperoleh bahwa terjadi peningkatan yang cukup signifikan dari Pra siklus, siklus 1 dan siklus II hal i ni tidak terlepas dari model pemeblajaran yang digunakan. Dengan pernerapan model Model Problem Based 
Learning Dengan Media Powerpoint mampu meningkatkan kemampuan siswa. Karena dalam proses pembejaranya siswa aktif menemukan dan menggali penegrahuannya sendiri sehingga pengetahuannya lebih bertahan lama. Meurut (Listiowati, 2013) Pembelajaran berbasis masalah atau Problem Based Instruction dikembangkan untuk membantu siswa mengembangkan kemampuan berpikir, pemecahan masalah, keterampilan intelektual, dan belajar berbagai peran dengan dewasa melalui pelibatan mereka dalam pengalaman nyata atau simulasi, serta menjadi siswa yang otonom dan mandiri. Model pembelajaran Problem Based Intruction menggunakan pendekatan pembelajaran siswa pada masalah kehidupan nyata. Problem Based Intruction dikembangkan untuk membantu siswa mengembangkan kemampuan berpikir, pemecahan masalah dan keterampilan intelektual, belajar berbagai peran, melalui pengalaman belajar dalam kehidupan nyata. Arends (Trianto. 2007) menjelaskan bahwa Problem Based Intruction merupakan pendekatan belajar yang menggunakan permasalahan autentik dengan maksud untuk menyusun pengetahuan siswa, mengembangkan inkuiri dan keterampilan berpikir tingkat lebih tinggi, mengembangkan kemandirian dan percaya diri.

Problem Based Intruction berpusat pada siswa. Problem Based Intruction merupakan salah satu dari berbagai model pembelajaran yang dapat digunakan guru dalam mengaktifkan siswa dalam belajar (Abbas et al., 2007). Guru berkewajiban menggiring siswa untuk melakukan kegiatan. Guru sebagai penyaji masalah, memberikan instruksi-instruksi, membimbing diskusi, memberikan dorongan dan dukungan yang dapat meningkatkan pertumbuhan inkuiri. Guru diharapkan dapat menberikan kemudahan belajar melalui penciptaan iklim yang kondusif dengan menggunakan fasilitas media dan materi pembelajaran yang bervariasi. Pelaksanaan Problem Based Intruction didukung dengan beberapa metode mengajar diantaranya metode ceramah, Tanya jawab, diskusi, penemuan dan pemecahan masalah. Problem Based Intruction mengacu pada inkuiri, kontruktivisme dan menekankan pada berpikir tingkat tinggi. Model ini efektif untuk mengajarkan proses - proses berpikir tingkat tinggi, membantu siswa membangun sendiri pengetahuannya dan membantu siswa memproses informasi yang telah dimiliki. Problem Based Intruction menggunakan masalah dunia nyata sebagai konteks untuk belajar tentang cara berpikir kritis dan keterampilan pemecahan masalah. Lingkungan belajar yang terbuka menuntut peran aktif siswa untuk melakukan penyelidikan terhadap masalah sehingga menjadi pembelajar yang mandiri. Penelitian yang dilakukan oleh (Suhita, 2019) menyatakan bahwa model pembelajaran Problem Based Instruction dapat meningkatkan kemampuan berpikir kritis peserta didik, dimana kemampuan berpikir kritis peserta didik meningkat dari setiap siklusnya. Kemudian penelitian yang dilakukan oleh (Anggis, 2017) menyatakan bahwa motivasi belajar siswa meningkat dari siklus sebelumnya dan lebih baik dari pembelajaran sebelum diberikan tindakan kelas dengan model pembelajaran Problem Based Instruction.

Model pembelajaran Problem Based Intruction akan lebih efektif lagi diterapkan apabila dipadukan dengan media power point. Media power point merupakan suatu software yang akan membantu dalam menyusun sebuah persentase yang efektif, profesional, dan juga mudah. Power point akan membantu sebuah gagasan menjadi lebih menarik dan jelas tujuannya jika dipersentasikan karena power point akan membantu dalam pembuatan slide, outline persentase, persentase elektronika, menampilkan slide yang dinamis, clip art yang menarik, yang semua itu mudah ditampilkan di layar monitor komputer. Manfaat menggunaan power point diantaranya adalah Manfaat program Power Point diantaranya adalah materi pembelajaran akan menjadi lebih menarik, penyampaian pembelajaran akan lebih efektif dan efesien, dan materi pembelajaran disampaikan secara utuh, ringkas, dan cepat melalui pointer-pointer mater (Jamilah, 2019; Purnomo, 2016). Penelitian yang dilakukan oleh (Minardi \& Akbar, 2020) menyatakan bahwa terciptanya Belajar mengajar yang lebih baik dengan memanfaatkan teknologi informasi khususnya Microsoft PowerPoint untuk membuat media belajar yang interaktif. Kemudian penelitian yang dilakukan oleh (Susanti et al., 2020) menyatakan bahwa media powerpoint pada pembelajaran bahasa Arab dalam kategori tinggi, yang dibuktikan dengan median 82,5.

Hasil penelitian ini sejalan dengan hasil penelitian yang dilakukan oleh Purwanto pada tahun 2016 dengan judul Penggunaan Model Problem Based Learning Dengan Media Powerpoint Untuk Meningkatkan Minat Belajar Siswa. Dalam penelitiannya disimpulkan bahwa model Problem Based Learning Dengan Media Powerpoint membuat pembelajaran di kelas menjadi lebih bermakna sehingga secara efektif dapat meningkatkan minat belajar siswa. Selanjutnya penelitian yang dilakukan oleh Hariata, dkk pada tahun 2017 dengan judul Pengaruh Model Pembelajaran Problem Based Instruction berbantuan Media Powerpoint Terhadap Hasil Belajar IPS. Hasil penelitian menunjukan bahwa terdapat perbedaan hasil belajar IPS antara kelompok siswa yang dibelajarkan dengan menggunakan model pembelajaran Problem Based Instruction berbantuan media powerpoint dan kelompok siswa yang dibelajarkan dengan menggunakan pembelajaran konvensional pada siswa kelas V SD di Gugus X Kecamatan Buleleng. 


\section{Simpulan dan Saran}

Berdasarkan penelitian yang telah dilakukan dapat disimpulkan bahwa: penerapan model pembelajaran problem based intruction dengan media power point secara efektif dapat meningkatkan prestasi belajar IPA siswa kelas VII B semester II SMP Negeri 3 Dawan Tahun pelajaran 2018/2019.

Berdasarkan simpulan di atas, dapat diajukan beberapa saran sebagai berikut: 1) Bagi guru, dalam proses pembelajaran guru hendaknya menerapkan berbagai macam metode/model pembelajaran yang inovatif, sehingga pembelajaran menjadi bermakna dan menyenangkan bagi siswa; 2) Bagi peneliti lain, walaupun penelitian ini sudah dapat membuktikan efek utama dari model/metode pembelajaran Problem Based Intruction dengan media power point dalam meningkatkan prestasi belajar, sudah pasti dalam penelitian ini masih ada hal-hal yang belum sempurna dilakukan, oleh karenanya disarankan kepada peneliti lain yang berminat meneliti topik yang sama untuk meneliti bagian-bagian yang tidak sempat diteliti; 3) Bagi pengembang pendidikan, selanjutnya untuk adanya penguatan-penguatan, diharapkan bagi peneliti lain untuk melakukan penelitian lanjutan guna memverifikasi data hasil penelitian ini

\section{Daftar Rujukan}

Anggis, E. V. (2017). Penerapan Pembelajaran Biologi Model Problem Based Instruction Scientific Untuk Meningkatkan Motivasi Belajar Siswa SMP. Mangifera Edu, 2(1), 1-7. https://doi.org/https://doi.org/10.31943/mangiferaedu.v2i1.13

Aryana, Wayan. 2003. Pengaruh Motivasi Belajar terhadap Prestasi Belajar IPA pada Siswa SMP Negeri 1 Denpasar. Ringkasan Hasil Penelitian yang Disampaikan dalam Seminar Hasil Penelitian Dosen Kopwil VIII, Tanggal 22-24 September 2003. DOI: 10.23887/jear.v4i1.23955

Azwar, Saifuddin. 2003. Penyusunan Skala Psikologi. Yogyakarta: Pustaka Pelajar.

Basrowi dan Sukidin. 2002. Metode Penelitian Kualitatif Perspektif Mikro. Surabaya. Insan Cendikia.

Dimyati dan Mudjiono. 2001. Belajar dan Pembelajaran. Jakarta: Dirjen Dikti.

Djamarah, Syaful Bahri. 2002. Prestasi Belajar dan Kompetensi Guru. Surabaya: Usaha Nasional.

Gregory, Robert J. 2000. Psychological Testing: History, Principles, and Applications. Boston: Allyn and Bacon.

Hariata, I. N. N., Pudjawan, K., \& Margunayasa, I. G. (2017). Pengaruh Model Pembelajaran Problem Based Instruction Berbantuan Media Powerpoint Terhadap Hasil Belajar Ips. MIMBAR PGSD Undiksha, 5(2). http://dx.doi.org/10.23887/jjpgsd.v5i2.10895

Jamilah, N. (2019). Pengembangan Media Pembelajaran Power Point Ispring Presenter Pada Materi Kosakata Bahasa Arab Peserta Didik Kelas V MI Tarbiyatul Athfal Lampung Timur. Al Mahāra: Jurnal Pendidikan Bahasa Arab, 5(1), 141-154. https://doi.org/10.14421/almahara.2019.051-08

Listiowati, Ayu Dwi, dan Antonius Tri Widodo. 2013. Penerapan Model Pembelajaran Problem Based Instruction dengan Pendekatan Predict-Observe-Explain. Jurnal Inovasi Pendidikan Kimia, Vol 7, No. 2, hlm. 1189-1200. Tersedia https://journal.unnes.ac.id/nju/index.php/JIPK/article/view/4419.

Minardi, J., \& Akbar, A. S. (2020). Pelatihan Pengembangan Media Pembelajaran Interaktif dengan Power Point untuk Peningkatan Kompetensi Guru SD. E-Dimas: Jurnal Pengabdian Kepada Masyarakat, 11(1), 96. https://doi.org/10.26877/e-dimas.v11i1.2747

Munirah. 2015. Sistem Pendidikan di Indonesia: antara keinginan dan realita. Auladuna, Vol. 2 No. 2 Hal. 233-245. Tersedia Pada: http://journal.uin-alauddin.ac.id/index.php/auladuna/article/view/879.

Purnomo, P. (2016). Pemanfaatan Media Belajar Powerpoint Untuk Meningkatkan Hasil Belajar Ipa Siswa Kelas Vii B Semester 2 Tahun 2015 Smp Negeri 3 Banyubiru. Phenomenon, 6(1). https://doi.org/http://dx.doi.org/10.21580/phen.2016.6.1.944

Purwanto, Wahyu, dkk. 2016. Penggunaan Model Problem Based Learning Dengan Media Powerpoint Untuk Meningkatkan Minat Belajar Siswa. Jurnal Pendidikan: Teori, Penelitian, dan PengembanganVolume: 1 Nomor: 9 Halaman: 1700-1705. http://dx.doi.org/10.17977/jp.v1i9.6721 
Suhita, S. (2019). Analisis Kemampuan Berpikir Kritis Matematis: Dampak Model Pembelajaran Problem Based Instruction. Desimal: Jurnal Matematika, 2(2), 189-195. https://doi.org/10.24042/djm.v2i2.4380

Sukmadinata, Nana Syaodih. 2012. Metode Penelitian Pendidikan. Bandung. PT. Remaja Rosdakarya.

Susanti, E., Ritonga, M., \& Bambang, B. (2020). Pengaruh Penggunaan Media Powerpoint Terhadap Minat Belajar Bahasa Arab Siswa. Arabiyatuna: Jurnal Bahasa Arab, 4(1), 179. https://doi.org/10.29240/jba.v4i1.1406

Trianto. 2007. Model-model Pembelajaran Inovatif Berorientasi Kontruktivistik. Jakarta; Prestasi Pustaka.

Yulidatullah, Silahuddin, dan Sadrina. 2018. Penggunaan Metode Problem Based Instruction (PBI) Untuk Meningkatkan Hasil Belajar dan Motivasi Siswa Pada Materi Pengukuran Nilai Resistor Kelas X di SMK Negeri 1 Darul Kamal Aceh Besar. Jurnal Ilmiah Pendidikan Teknik Elektro,Vol.2, No.1, Februari 2018, hal. 39-48. http://dx.doi.org/10.22373/crc.v2i1.3259 